taken a principal part in lecturing to them. A noteworthy feature of his teaching has been his wide outlook and his insistence on the study of plants in the field; in this connexion he has conducted many vacation classes in the Lake District and elsewhere. $\mathrm{He}$ is one of the editors of the Ecological Society's "Biological Flora of the British Isles", and has encouraged much research on interesting plants.

Dr. Richards has travelled extensively in connexion with his studies of tropical rain forests. In 1929 he was in British Guiana, in 1932 he visited Sarawak, and during 1934-35 and 1947-48 he was the leader of Cambridge botanical expeditions to Nigeria. In addition to publishing papers on various aspects of tropical rain forests he has written a comprehensive book about them, now in course of publication. As a bryologist, Dr. Richards is outstanding, and he is convinced that mosses and liverworts offer a favourable field, hitherto largely unexplored, for experimental studies. He has taken great interest in the Cambridge Botanic Garden. His Cambridge colleagues, while regretting Dr. Richards's departure, congratulate him warmly on his advancement. They prophesy that he will have a very successful tenure of the chair at Bangor. With large developments pending there, Dr. Richards's organising ability and co-operative nature should be valuable assets.

Engineerithg at Manchester: Prof. A. H. Gibson

Prof. A. H. Giflon is to retire from the Beyer chair of engineerfids the University of Manchester in September. $\mathrm{He}$ will then have occupied this famous paipkr twenty-nine years, with a distinction well vort $y$ of the traditions created by his master, Oshe Reynolds. Both at Manchester and in his inspiring re-organisation of the Engineering Department of the University of St. Andrews between 1909 and 1920, Prof. Gibson has maintained a firm belief in Reynolds's conception of the aims and methods of university education in engineering : to teach fundamentals and "the physical laws on which mechanics as a science are based" - and to eschew "spoonfeeding'. His original work is described in an impressive series of books and papers remarkable for the clarity of his writing, the directness of his arguments and the skill of his experimenting. A very few titles taken at random reflect the range of his interests : "On the Depression of the Filament of Maximum Velocity in a Stream flowing through an Open Channel" ; "On the Local Intensification of Draught produced in a Horizontal Air Current by the Presence of an Inclined Rod"; "A Study of the Circular-Arc Bow Girder" ; "The Behaviour of Bodies Floating in a Free or a Forced Vortex" ; "Piston Temperatures and Heat Flow in High Speed Petrol Engines"; "Tidal Model of the Severn Estuary".

Prof. Gibson was for a time simultaneously a member of the Severn Barrage Committee and of the Air Ministry Engine Research Committee. Since 1926, however, his special interest has been in the use of hydraulic scale-models, and a natural outcome of his great efforts in this field was the establishment in 1946 of the Hydraulics Research Organisation of the Department of Scientific and Industrial Research. At the present time, no fewer than six university chairs are occupied by former students and members of his staff, and his personal influence among students and practising engineers alike is as significant as (to quote the citation of the Ewing Medal awarded to him in 1938) his "specially meritorious contributions to the science of engineering in the field of research". \\ Prof. W. R. Hawtidis}

William Rede Hayyrhorne, who is succeeding Prof. A. H. Gibson, educated at Trinity College, Cambridge. He offained first-class honours in the Mechanical gionces Tripos and was awarded the Rex Moir Prle. On leaving Cambridge he joined the firm of $B^{\text {trbcock }}$ and Wilcox, where for a short time ho wofked on boiler research. He then obtained a Chnmfonwealth Fund Fellowship, which enabled him to go to the United States and work for two years at the Massachusetts Institute of Technology on combustion research. On the completion of this work he returned to England to his old firm. When the Second World War broke out he joined the research staff of the Air Ministry, being later transferred to the Ministry of Aircraft Production. He worked for a short time at the Aircraft Testing Establishment at Boscombe Down and then moved to the Engine Department of the Royal Aircraft Establishment at Farnborough. At Farnborough he was quickly drawn into the work proceeding there on gas turbines, and in a short time was put in charge of this work. In 1944 Dr. Hawthorne was transferred to the head. quarters branch of the work, where he became responsible for directing the work on gas turbine research. At the end of the War he returned to the United States and took up a post as lecturer at the Massachusetts Institute of Technology, where he is at present the Westinghouse professor of gas turbines. Prof. Hawthorne is known for the researches directed by him on gas turbines during the War and for his interest in the combination of fluid flow and combustion usually termed 'gas dynamics'.

\section{Scientific Civil Service : Promotion of Individual Research Workers}

IT is anyounced that additional special posts have been created this year for individual research workers of expeptional quality under provisions included in the White Paper on the Scientific Civil Service (Cmd. $6679,1945)$. In recognition of their personal work, promotion to these posts in the grade of senior principal scientific officer (salary scale, $£ 1,320-£ 1,520$ ) has been awarded to the following officers: C. A. Adams (Ministry of Supply), a mathematical physicist whose researches in ballistics and in ultra high-speed photography have led to results of the highest importance ; Dr. H. A. Baylis (British Museum (Natural History) ), a systematic zoologist, who has made notable contributions to our knowledge of the parasitic worms, particularly those of importance in medical and veterinary work; Miss F. B. Bradfield (Ministry of Supply), whose numerous contributions in aerodynamics to aeronautical research have been of outstanding scientific and industrial value ; $H$. C. Calpine (Admiralty), a pioneer in radar, who has contributed in a large measure to the successful development of naval fire-control radar, and is now engaged on research into the difficult problems of weapon control ; W. G. Campbell (Department of Scientific and Industrial Research), who has made many original contributions to the chemistry of wood, some of considerable technical importance; J. N. Carruthers (Admiralty), whose investigations on tidal currents have earned for him an international reputation, and who has brought together a valuable oceanographical library; J. S. Dick (Ministry of Supply), a physical chemist and a leading authority on pyrotechnics who has a long record of outstanding achievements in this field; J. W. Fisher (Admiralty), 
who is engaged on theoretical and experimental investigations in hydrodynamics and acoustics with special application to the reduction of ship noise and to the examination of cavitation phenomena; H. L. Green (Ministry of Supply), who has made important contributions to the study of particle suspensions and has developed this branch of physics to a very high degree of precision; J. S. Hey (Army Operational Research Group, War Office), who, in the course of his work on radar and the ionosphere, has carried out important investigations on abnormal radiations from the sun and the galaxy and on echoes due to meteors; Dr. H. London (Ministry of Supply), a physicist whose outstanding work before the War was on the effect of high frequencies on supra-conductivity ; more recently, he has worked on the separation of stable isotopes, and has achieved results of considerable practical and theoretical importance in the separation of carbon-thirteen by low-temperature distillation; A. R. Rangabe (Admiralty), who was concerned prior to the War with the development in industry of electronic tubes of all descriptions; his ingenuity and flair for developing manufacturing techniques, and his understanding of the problems and difficulties in manufacture, have particular significance at the present time; Dr. E. Roberts (Ministry of Supply) has a long and successful record of important and fundamental work on diverse aspects of the chemistry and production of explosives.

National Institute of Sciences of India: New Fellows

AT the peeting of the National Institute of Sciences of Indig on January 4, 1949, the following elections were announced. Honorary Fellows : Prof. Louis de Broglie, professor of theoretical physics, Poincaré Institute, Sorbonne, Paris; Prof. Hans von Euler, emeritus professor of chemistry, University of Stockholm; Dr. Harlow Shapley, director of Harvard Observatory, Cambridge, Mass.; Prof. Georg Tischler, Botanical Institute, University of Kiel. Ordinary Fellows: Dr. J. L. Bhaduri, lecturer in zoology, University of Calcutta; Dr. S. Bhagavantam, scientifie liaison officer for India in the United Kingdom; Dr. S. K. Chakrabarty, director, Colaba and Alibag Observatories, Bombay; Dr. D. Chakravarti, lecturer in chemistry, University of Calcutta ; Dr. M. Damodaran, assistant director, National Chemical Laboratories, Delhi ; Dr. B. K. Das, professor of zoology, Osmania University, HyderabadDeccan; Dr. Kurien Jacob, palæobotanist, Geological Survey of India, Calcutta ; Dr. T. S. Mahabale, lecturer in botany, Royal Institute of Science, Bombay; Dr. H. K. Mitra, refractories engineer, Tata Iron and Steel Co., Ltd., Jamshedpur; Dr. K. Mitra, officer in charge, Nutrition Scheme, Public Health Lab. oratories, Patna; Dr. A. H. Pandya, director, Hindusthan Aircraft, Bangalore; Dr. N. Parthasarathy, geneticist, Indian Agricultural Research Institute, New Delhi ; Dr. C. Racine, professor of mathematics, Loyola College, Madras; Dr. K. C. Sen, director, Indian Dairy Research Institute, Bangalore; Dr. R. S. Varma, reader in mathematics, University of Lucknow.

\section{Production of Radioactive Isotopes in Britain}

THE large atomic pile (BEPO) at the Atomic Energy Research Establishment, Harwell, has begun opelating for the production of radioactive isotopes. When it is working at full power later this year, it will be able to produce all the artificial radioactive isotopes required in Great Britain by medical, indus- trial and other research workers. More isotopes will also be available for export, and it is expected that a steadily increasing demand for them will develop overseas. Materials irradiated in the new pile will be twenty times more active than those so far irradiated in the first and smaller pile. The new pile has. a rated output of $6,000 \mathrm{~kW}$. and was designed primarily for experimental purposes. The smaller pile, designed to develop about $100 \mathrm{~kW}$. of heat, started up in August 1947 and has been producing radioactive isotopes since September of that year. Present production is about a hundred and fifty specimens a month.

\section{Vegetation-types Map of Tanganyika

THE Geographical Regiew has published a reprint of an article frefaro January 1949 issue entitled "A Vegetation yyes Map of Tanganyika", by the late Clemprf Gillman. This study of the natural vegetati Mf Tanganyika Territory by a man who had prolound knowledge of the country and of its pefand is one that should be used as a basis for wise planning, and development. The classification is strictly physiognomic and provides an essential basis for further ecological and geographical investigations. The vegetation of the greater part of Tanganyika Territory is a mixture of woodland or bushland with grassland, the distribution being primarily determined by variations of soil and water conditions and the use made of them by man, although, as the author points out, topography and tectonics influence the climate and distribution of vegetation. The main types shown on the coloured map on a scale of $1: 2,000,000$ include forest, woodland, bushland and thicket, grassland, permanent swamp vegetation, desert and semi-desert, and vegetation actively induced by man in native and non-native cultivations. The term "actively induced vegetation" includes the mixed and constantly changing pattern of cultivated crops, pastures and interspersed remnants of the original vegetation and of scattered small areas of secondary growth. Complexes of vegetation occurring in close conjunction are shown on the map symbolically, using the colour of the dominating type for the ground colour with intrazonals or complexes shown by circles or dots in the colour of their type. Sequences of vegetation types caused by regularly repeated physiographic or hydrographic conditions are shown as "catenas"-a word originally applied to soils in East Africa. The map brings out at a glance the small remnants of evergreen forest left on the main watersheds, and the author stresses the urgency of the threat to the country's water resources. The map also rectifies a commonly held exaggerated view of the size of alien plantations and farming settlements, which appear as tiny specks compared with the great extent of native-cultivated land.

\section{Statistical Estimation}

THE current mather frtical theories concerned with the estimation of $0 \mathrm{r}$ more unknown parameters in a frequeng findion have been the occasion of mucle conf roversy, and the absence of a systematic revie of this field at a sufficiently elementary level has M. 2 a serious obstacle to the student. Two recent articles by Dr. Leon Solomon published in the Journal of the Institute of Actuaries Students' Society (7, 144 and 213) go a long way towards meeting this need, and form a most welcome addition to the literature. The first article is chiefly concerned with 'point' estimation. The concept of sufficiency is discussed, the minimum-variance theorem is proved, and 